\title{
Shell Middens of the Coast of Balochistan
}

Paolo Biagi*

Department of Asian and North African Studies, Ca' Foscari University - Venice, Venice, Italy

According to Arrian, the Greek historian, the region that extends west of the Hab River, which divides Sindh in the east from Las Bela in Balochistan in the west, has been known since the Hellenistic times to have been settled by the Oreitai, an ethnic group similar to the Ichthyophagi (McCrindle, 1973), although no archaeological trace of their presence has ever been recorded during the surveys made in the area (De Cardi, 1983; Khan, 1964, 1979; Raikes, 1967-1968; Stein, 1943). In effect the first traces of prehistoric shellfish eaters were discovered by chance, when Professor A. R. Khan of Karachi University showed me, in his museum, a few decolored specimens of Terebralia palustris mangrove shells he had collected a few years before along the shores of a small bay called Daun, some $15 \mathrm{~km}$ south of Cape Gadani, in Las Bela province. A brief visit paid to Daun in January 2000 led to the discovery of a few shell middens (Biagi, 2003-2004, 2004, 2013), while many others were recovered between 2004 and 2008, south of the same bay and on the Pleistocene marine terrace that raises from the beach just to the southeast (Biagi, Fantuzzi, \& Franco, 2012). Further surveys conducted along the southeastern coast of Las Bela in the following years have shown that shell middens with different characteristics and variable chronology exist in many places (Fig. 1) among which are Gadani and Phuari Headlands (Biagi, Nisbet, \& Girod, 2012-2013) and the shores of Lake Siranda (Biagi, 2011; Biagi, Girod, Nisbet, \& Fantuzzi, 2013a; Biagi, Girod, \& Nisbet, 2013b). Shell middens are places where the debris from eating shellfish and other food has accumulated over time. They can contain shellfish remains; bones of fish, birds, and land and sea mammals used for food; charcoal from campfires; and tools made from stone, shell, and bone. Shell middens tell us a lot about Aboriginal activities in the past. The types of shells in a midden can show the type of marine environment that was used and the time of year when Aboriginal people used it (Kristiansen, 2002).

\section{The Balochistan Sites}

\section{Daun}

As mentioned above, prehistoric shell middens were discovered in three distinct spots around the Bay of Daun and its surroundings, where they cover a roughly rectangular area between $24^{\circ} 59^{\prime} 18.08^{\prime \prime}-25^{\circ} 00^{\prime} 27.29^{\prime \prime} \mathrm{N}$ and $66^{\circ} 42^{\prime} 19.35^{\prime \prime}-66^{\circ} 43^{\prime} 07.22^{\prime \prime} \mathrm{E}$ (Fig. 2). They are represented by heaps or scatters of fragmented mangrove shells, mainly Terebralia palustris, although specimens of Telescopium telescopium and Anadara uropigimelana also occur. Among the sites, a special role was undoubtedly paid by shell midden 1 (Fig. 3), on the surface of which 50 pitted crushing stones with pecked round or oval grooves were recorded, most probably anvils used for opening shellfish (Figs. 4, 5, and 6). The site also yielded a few chipped stone artifacts made from both

\footnotetext{
*Email: pavelius@unive.it

*Email: paolo.biagi@unive.it
} 


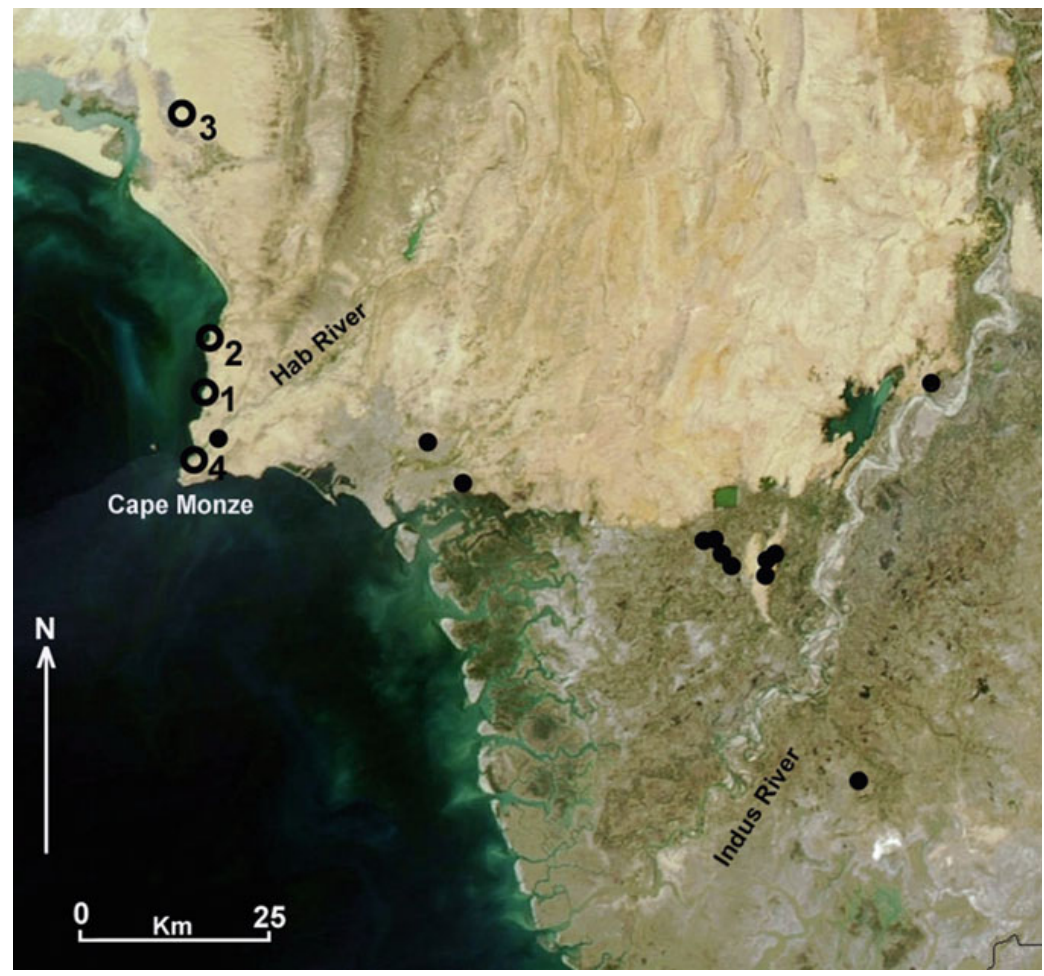

Fig. 1 Location of the sites mentioned in the text: 1 Daun, 2 Capes Gadani and Phuari, 3 Lake Siranda, 4 Sonari. The smaller black dots show the location of other radiocarbon dated mangrove and marine shell sites in the Indus Delta (Sindh)

Gadani dark red flint and other varieties of chert most probably derived from a source located in the interior Las Bela. In addition to site 1, site 10 is also unique. Located somewhat far from the others, well sheltered between volcanic rocks, its surface is characterized by mangrove gastropods in a very high state of fragmentation (Fig. 7). Narrow bladelet small cores (Fig. 8) and geometric, microlithic chipped stone tools, among which are one lunate and one trapeze, were collected from its surface (Biagi, Fantuzzi, \& Franco, 2012, Fig. 12). Other shell middens located further south are sometimes grouped together. Their distance from the present Arabian Sea coast varies from 60 to $700 \mathrm{~m}$ (Fig. 9). Seventeen out of 29 sites have been radiocarbon dated mainly from samples of Terebralia palustris shells. The analyses yielded very interesting results, which help us follow the environmental changes that took place in the surroundings of the bay between the first half of the seventh and the end of the fifth millennium BP (Fig. 10). They show that Neolithic shellfish gatherers first visited the bay when favorable conditions led to the establishment of mangrove environments. The area was almost uninhabited during the Copper Age and visited again during the Mature Indus Civilization, to be finally abandoned around the end of the Bronze Age. 
Encyclopaedia of the History of Science, Technology, and Medicine in Non-Western Cultures DOI 10.1007/978-94-007-3934-5_10169-1

(C) Springer Science+Business Media Dordrecht 2014

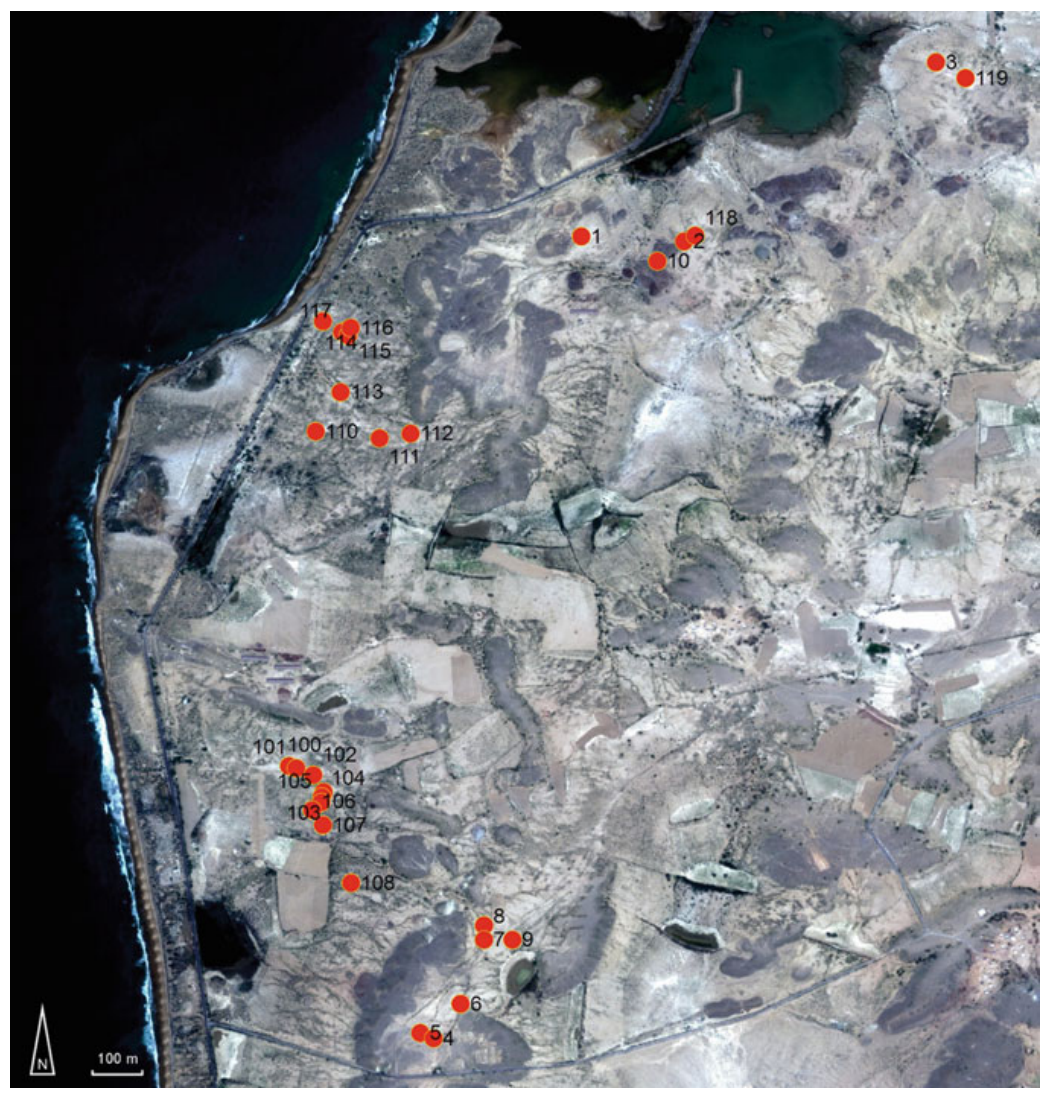

Fig. 2 Daun: distribution map of the shell middens with their respective numbers 
Encyclopaedia of the History of Science, Technology, and Medicine in Non-Western Cultures DOI 10.1007/978-94-007-3934-5_10169-1

(C) Springer Science+Business Media Dordrecht 2014

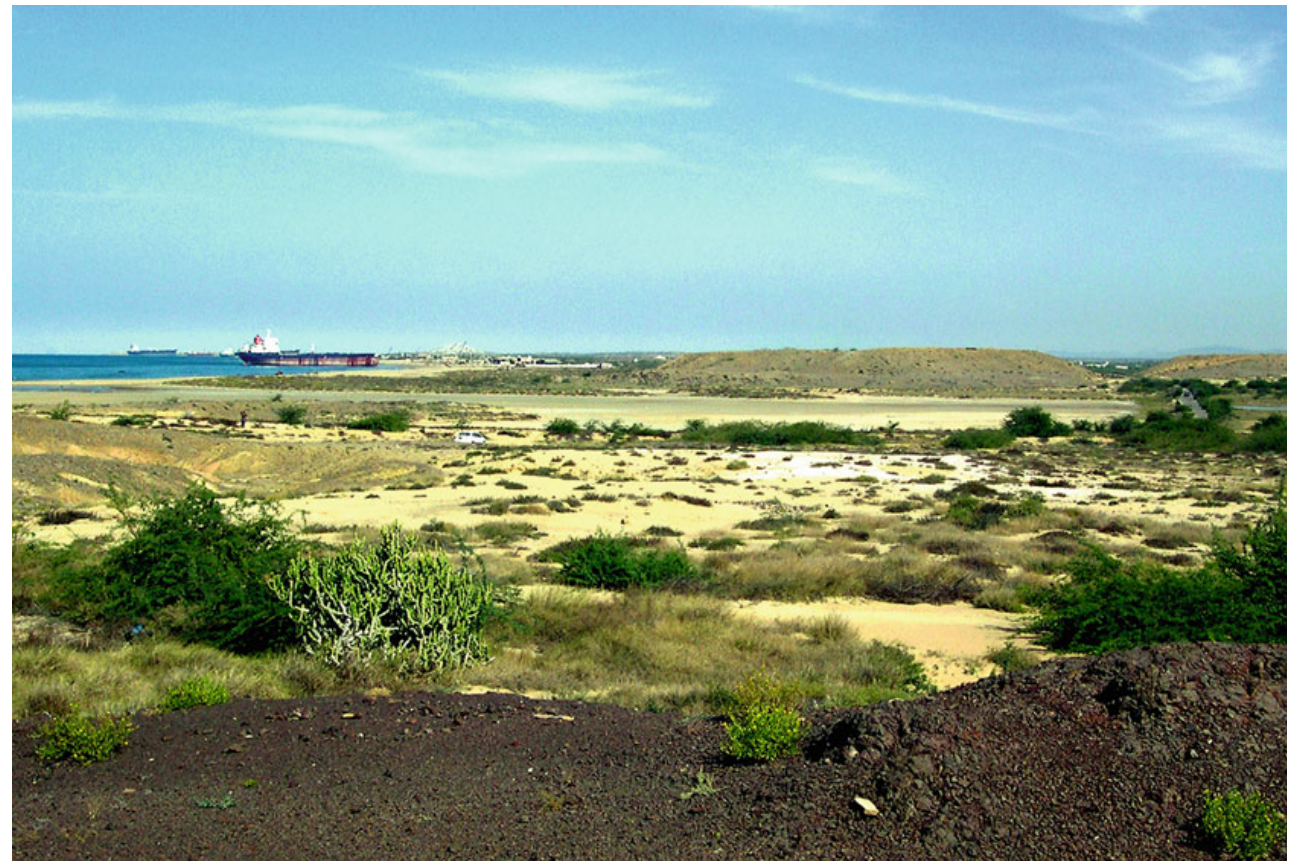

Fig. 3 Daun: shell midden Daun 1, in the center of the picture taken from Daun 10

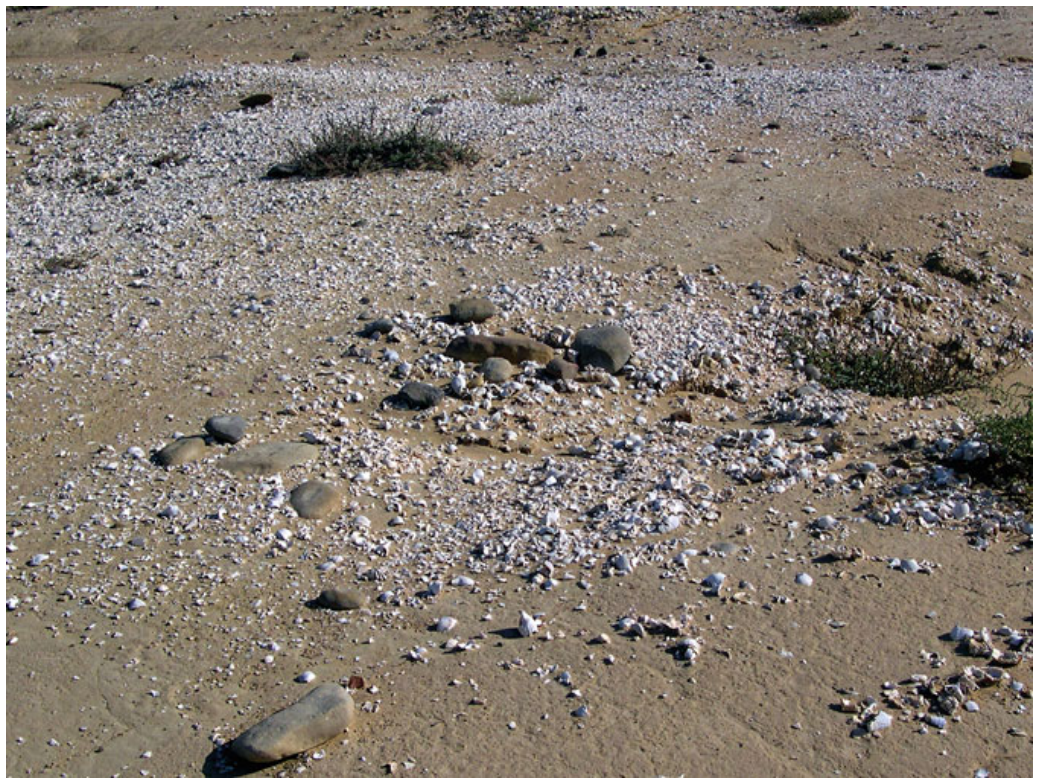

Fig. 4 Daun: shell midden Daun 1, with a concentration of ground stone anvils in its center 


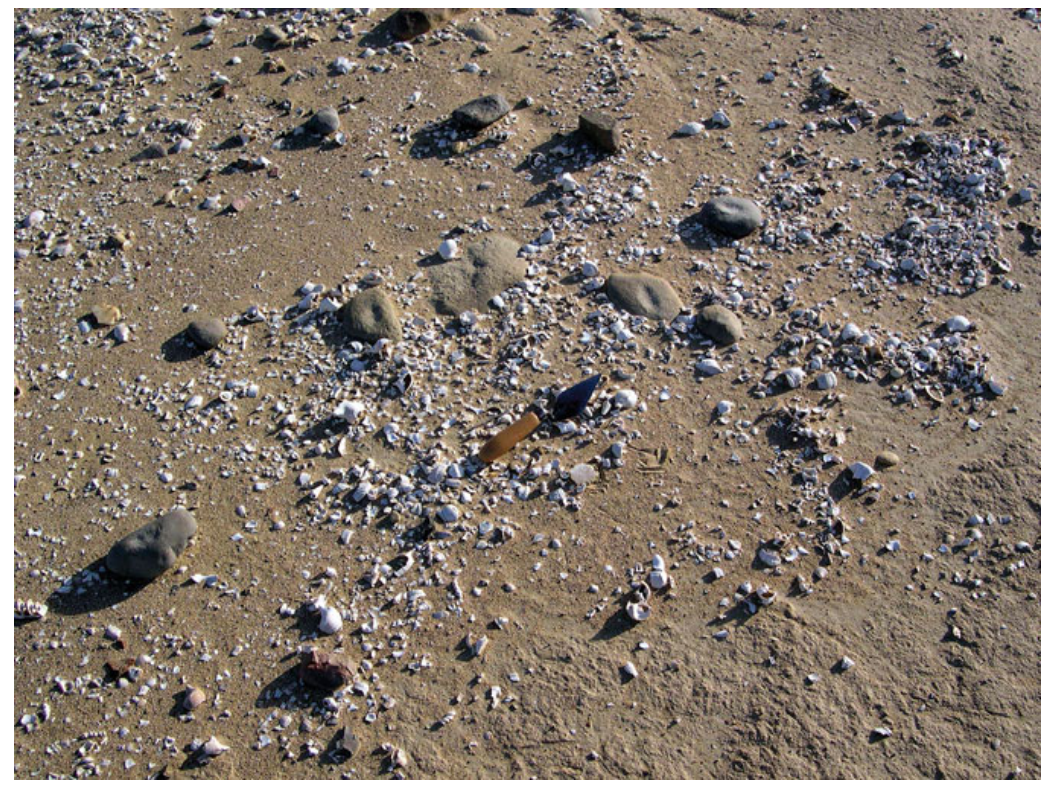

Fig. 5 Daun: characteristic ground stone anvils, in the center of Daun 1

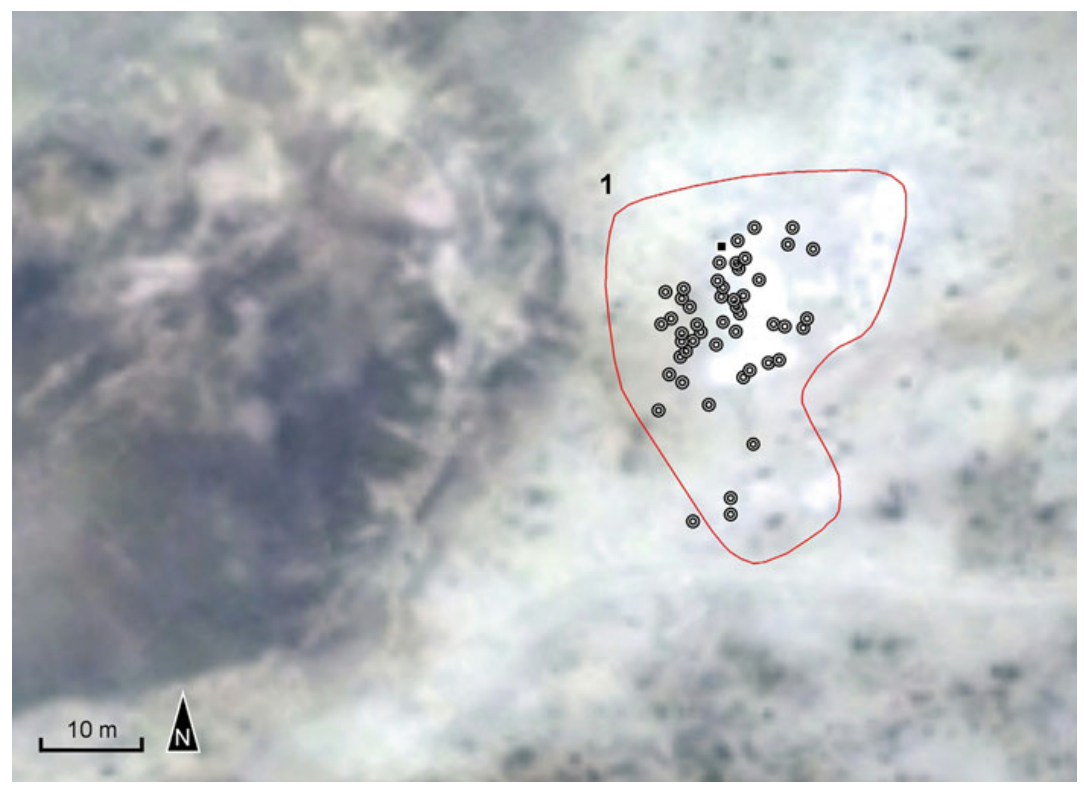

Fig. 6 Daun: distribution map of 50 ground stone tool anvils recorded from Daun 1 


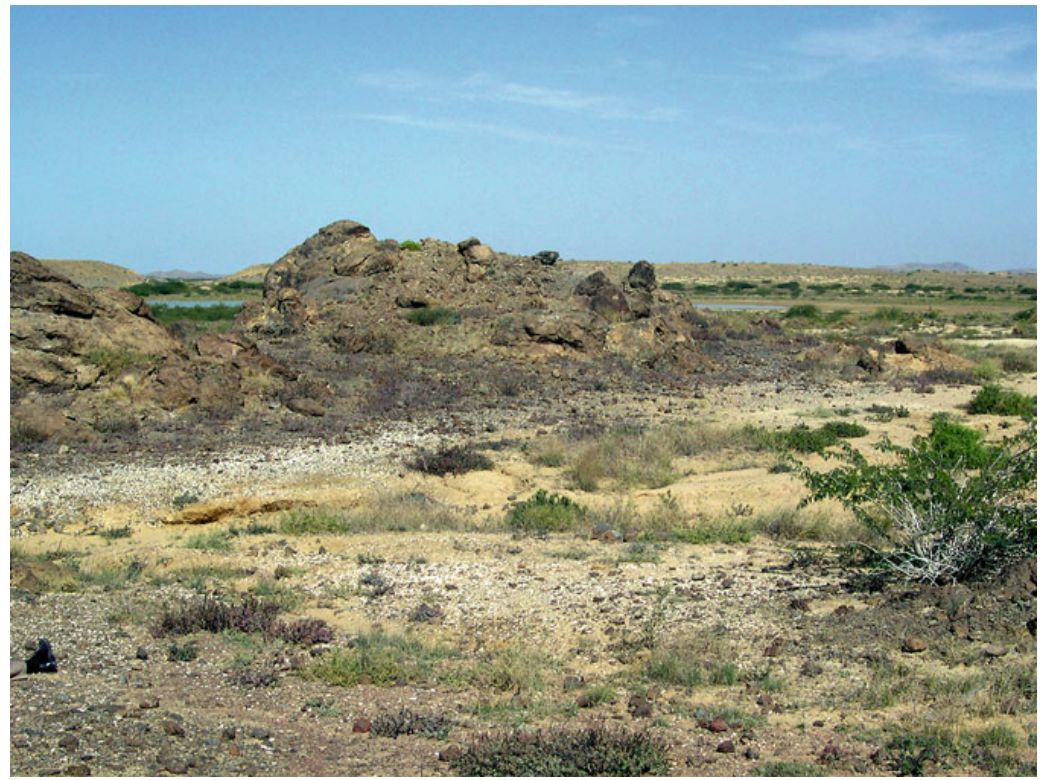

Fig. 7 Daun: shell midden Daun 10 photographed from the south

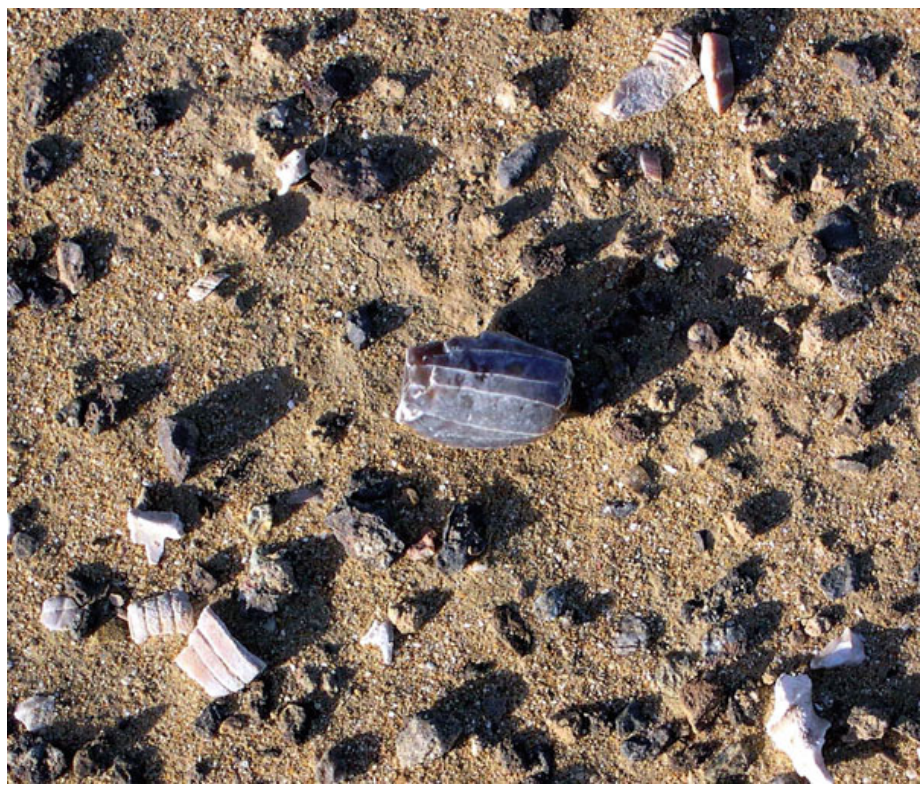

Fig. 8 Daun: flint microlithic prismatic core with microbladelet detachments on the surface of Daun 10 


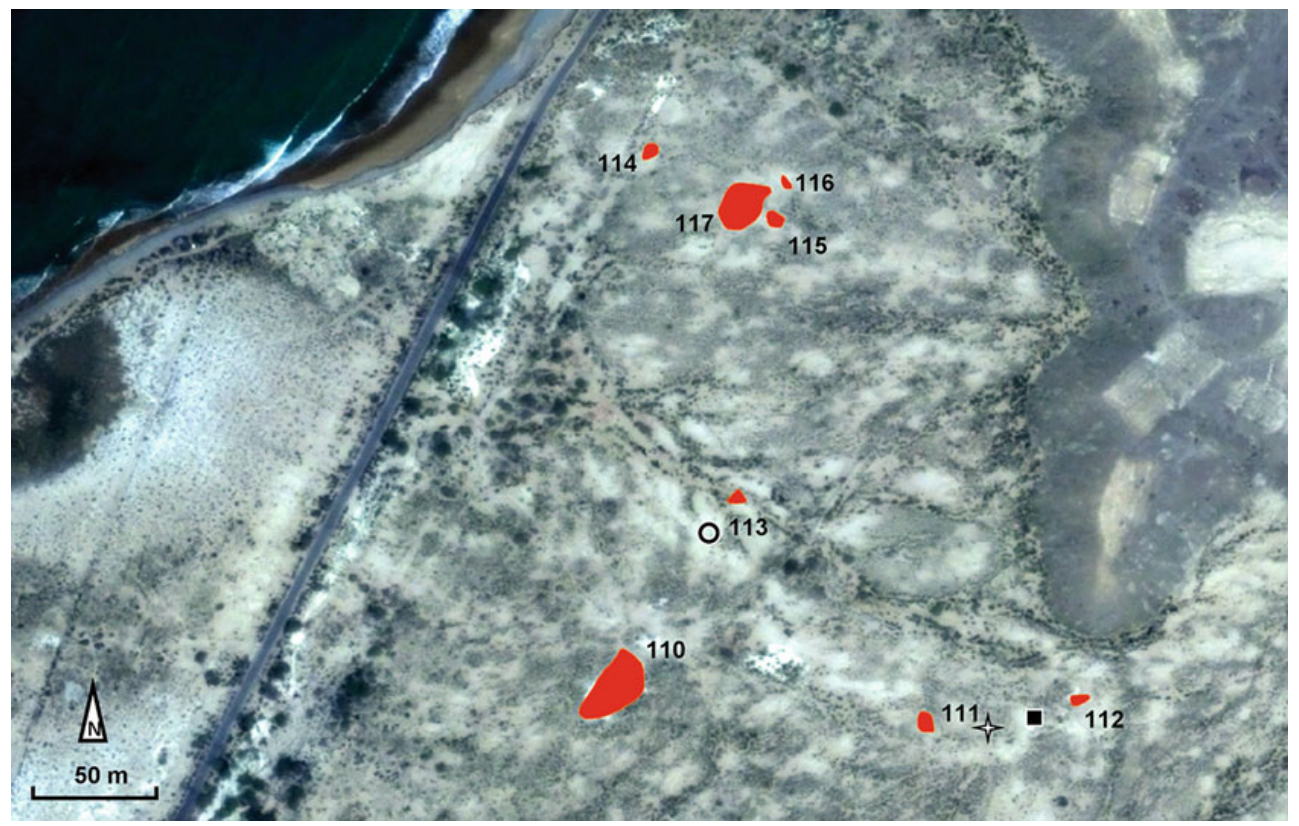

Fig. 9 Daun: distribution map of the shell middens Daun 110 to Daun 117 with the location of one net sinker (star), one anvil (circle), and one flint core (square)

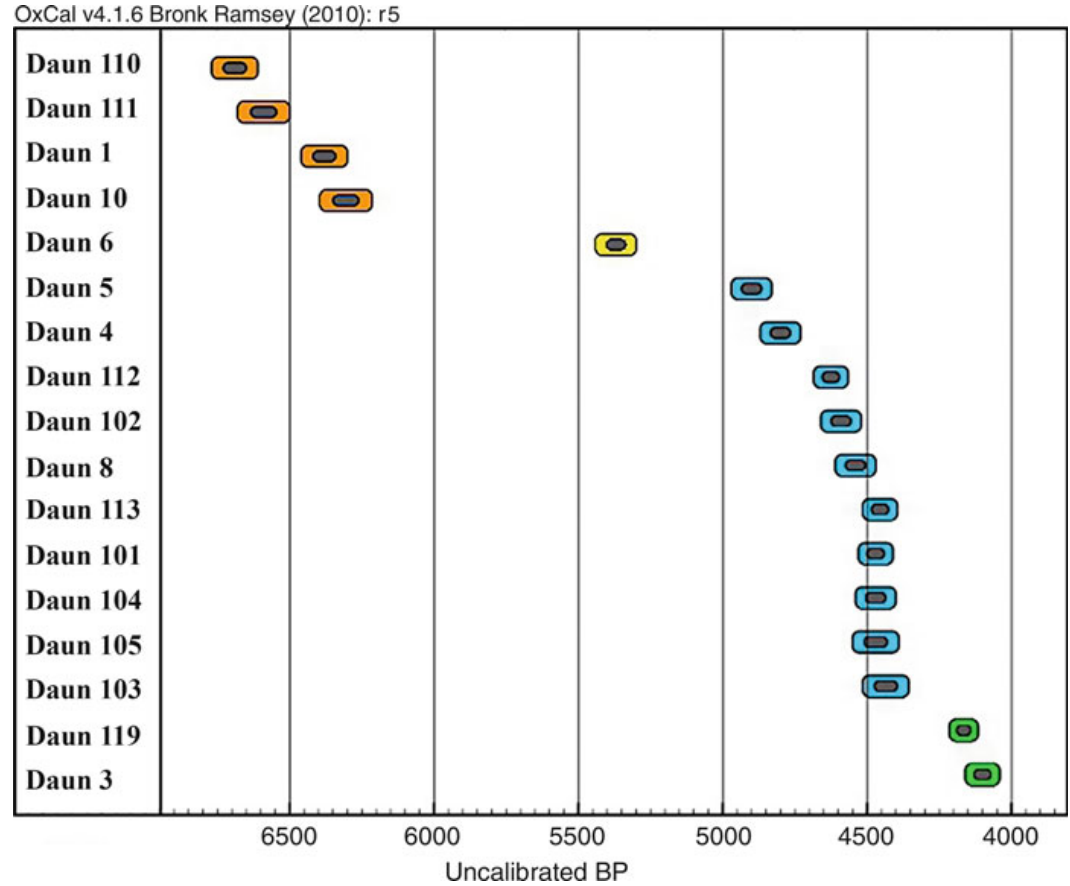

Fig. 10 Daun: scatterplot of the uncalibrated BP radiocarbon dates obtained from mangrove and marine samples from the shell middens 


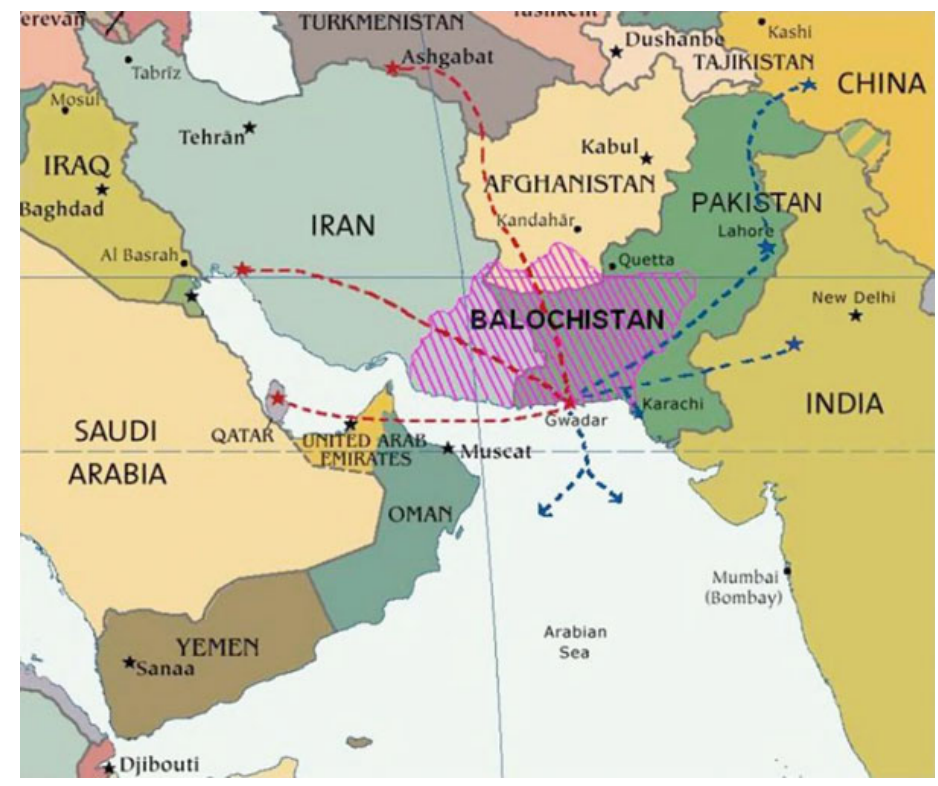

\section{Gadani and Phuari Headlands}

Gadani is a small promontory, $87 \mathrm{~m}$ high, easy to recognize because of the pinkish color of the Parh limestone formations that characterize it (Khan, 1973). The cape is separated from Ras Phuari, some $3.5 \mathrm{~km}$ to the south, by a strip that runs in NNE-SSW direction, in the center of which flows a small, seasonal stream called Kunari Dora (Fig. 11). The territory has a complex sedimentary sequence, characterized by Bela Ophiolites (Sarwar, 1992) and Parh limestones (Naseem, Sheikh, \& Qadeeruddin, 1996-1997), the latter containing good quality, dark red flint nodules that were exploited in prehistory since the Mesolithic for making tools (Figs. 12, 13, and 14). Prehistoric sites, mainly shell scatters containing a few chipped stone artifacts and potsherds, were discovered on both capes during three brief surveys conducted in 2002, 2011, and 2012 (Biagi, Nisbet, \& Girod, 2012-2013). The AMS results obtained from four mangrove (Terebralia palustris) and marine (Purpura panama) shell samples have shown that both capes were sporadically settled during the middle of the fifth millennium BP, when mangrove swamps flourished in the area, and the end of the second millennium BP, when the seasonal gathering of marine shellfish had taken place (Fig. 15).

\section{Lake Siranda}

Intensive surveys carried out between 2011 and 2013 by the Italian Archaeological Mission have shown the importance of the archaeological region surrounding Lake Siranda, a shallow basin some nine miles long and two miles wide that receives seasonal water from the Watto River and is sometimes filled with summer monsoon rains. Siranda depression, which is considered by some authors a playa remnant of the Sonmiani Lagoon (Snead, 1966, 1969), formed by a gradual recession of the sea (Minchin, 1907), is delimited by sand dunes that elongate in north-south direction along its western side (Snead \& Frishman, 1968). Its shores are dotted with prehistoric shell middens that are easy to recognize because of the presence of mangrove shell fragments, mainly Telescopium 


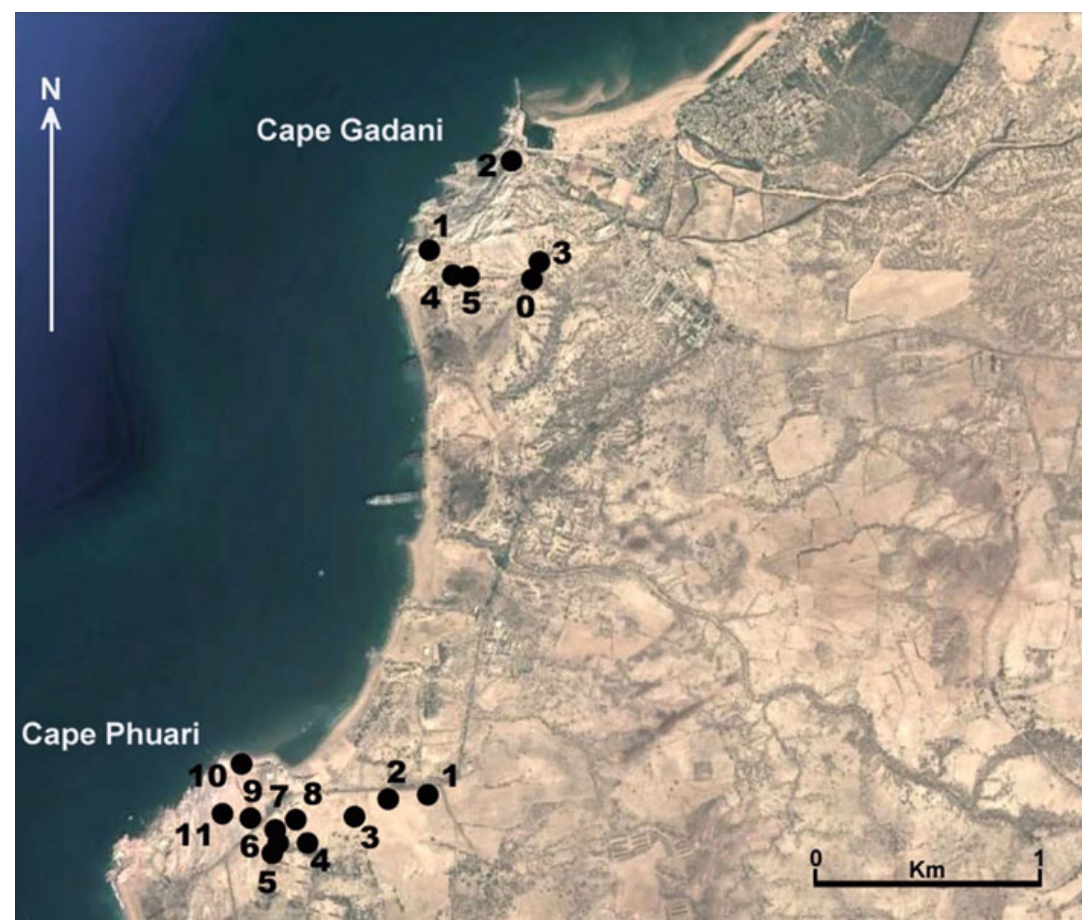

Fig. 11 Distribution map of the sites discovered at Capes Gadani, in the north, and Phuari, in the south

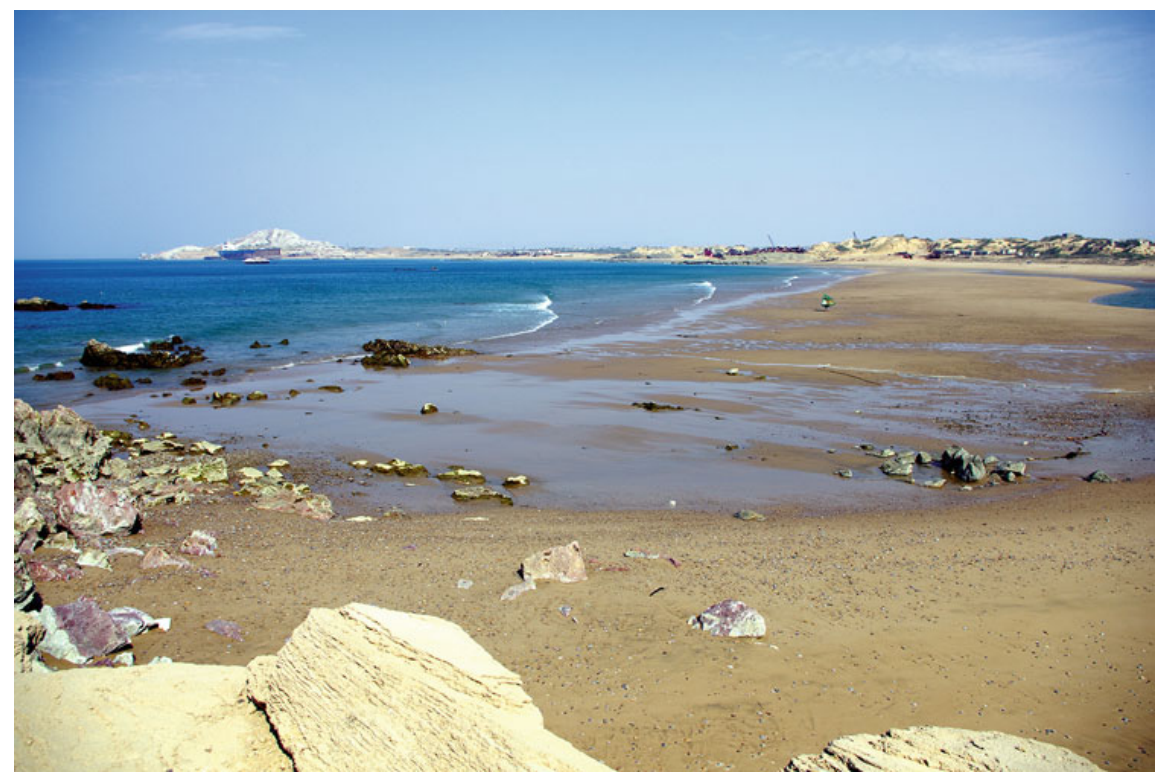

Fig. 12 Cape Gadani, in the background, photographed from Cape Phuari

telescopium and Terebralia palustris gastropods. Many sites have been discovered along the southeastern low terrace of the lake. Given that more that 70 shell middens of different shape, size, and age have been so far discovered, we can assume that Siranda was repeatedly visited or temporarily settled for the gathering of shellfish mainly during the Neolithic (Fig. 16). Copper and 


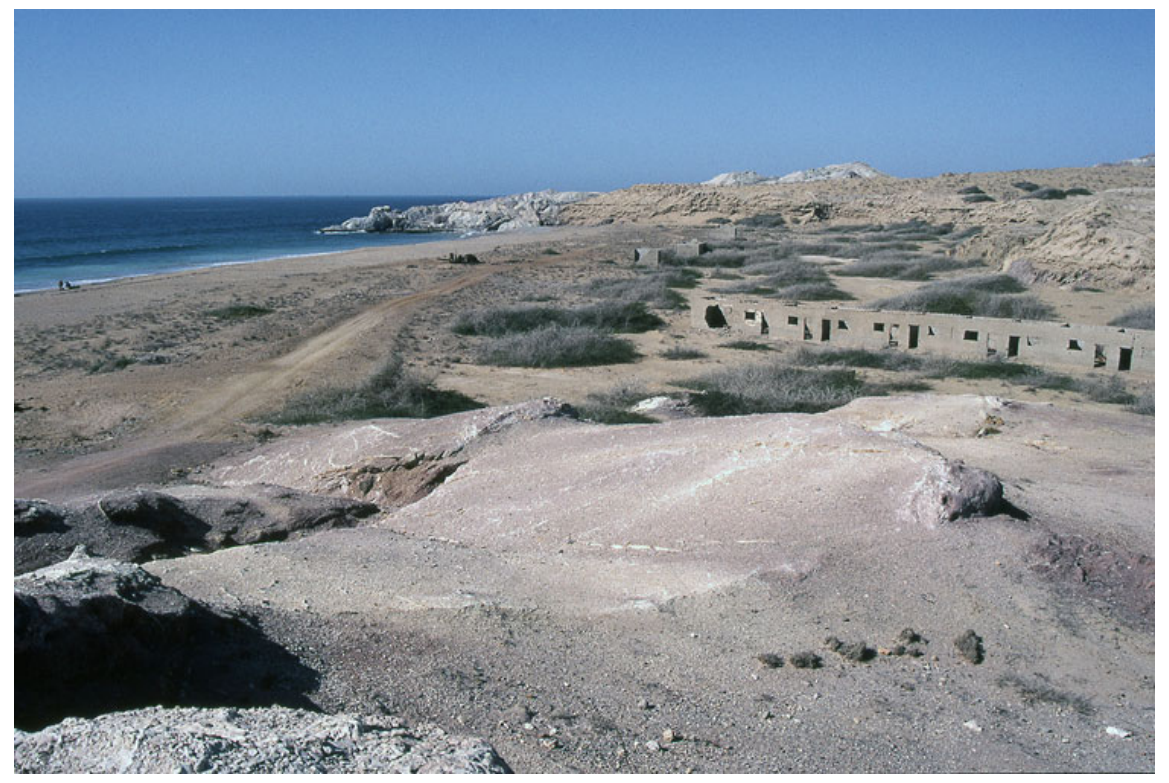

Fig. 13 Cape Gadani: area in which the prehistoric sites 4 and 5 were discovered in the center of the photograph. The cape is in the background

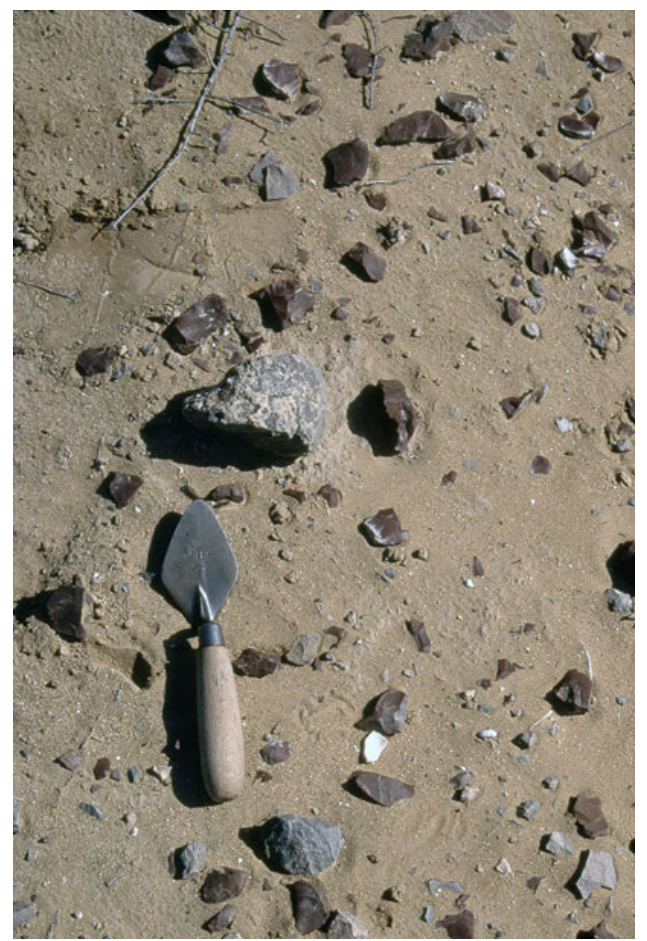

Fig. 14 Cape Gadani: dark red Gadani flint natural block and tools on the surface of one of the prehistoric sites 


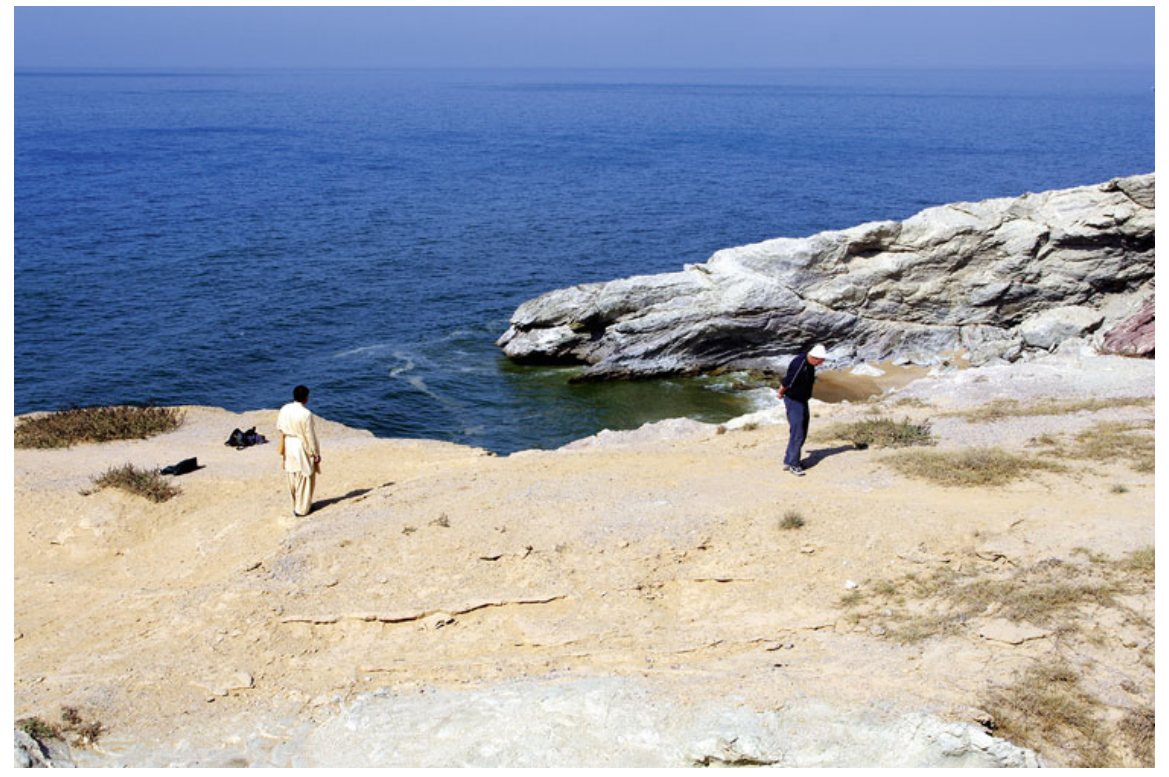

Fig. 15 Cape Gadani: site 1 that consists of a scatter of Purpura panama marine shells

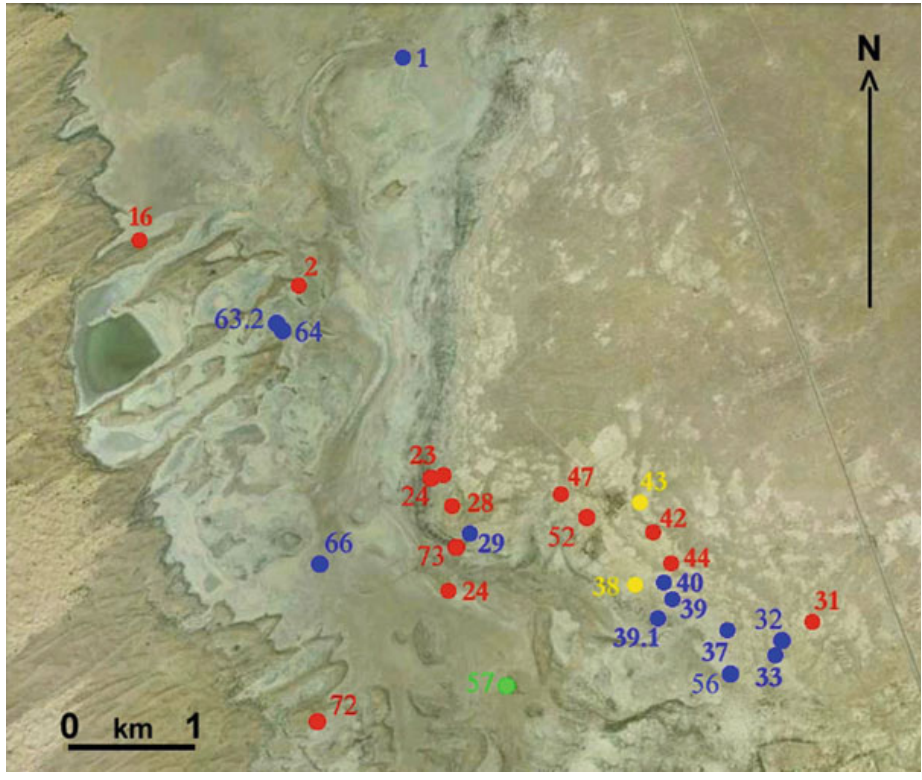

Fig. 16 Lake Siranda: distribution map of the AMS-dated shell middens. Eighth millennium BP (yellow), seventh millennium BP (blue), sixth millennium BP (red), and fifth millennium BP sites (green)

Bronze Age sites have also been recovered as shown by the results from the AMS dates obtained from 27 middens, which attribute them to a period comprised between the second half of the eighth and the second half of the fifth millennium BP (Fig. 17). Along the lake perimeter, which shows different morphologic characteristics region by region (Fig. 18), shell middens occur as real mounds up to $3 \mathrm{~m}$ thick (Fig. 19), small mangrove shell scatters (Figs. 20 and 21), and thin, almost circular 


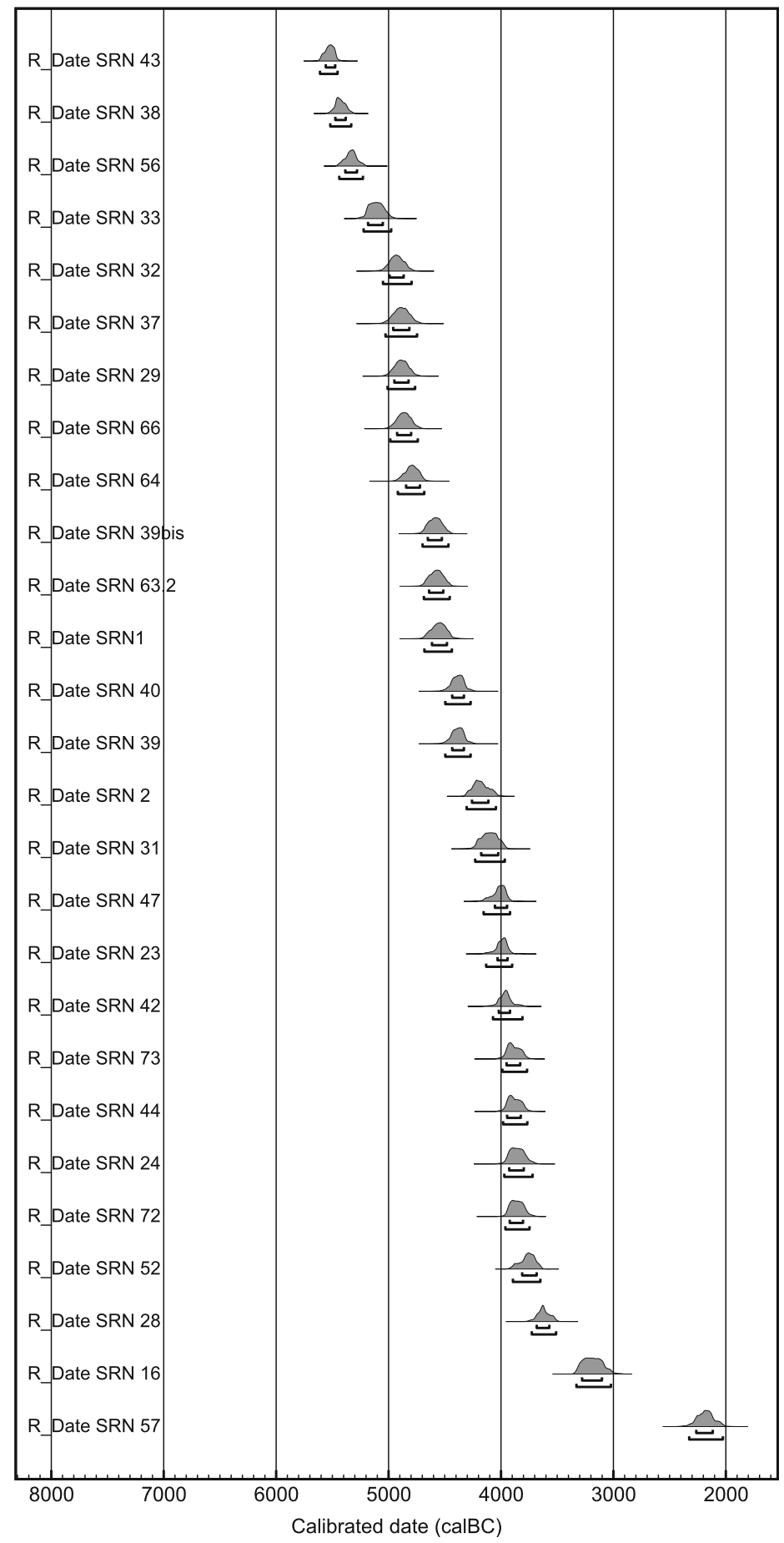

Fig. 17 Lake Siranda: scatterplot of the AMS calibrated dates obtained from the shell middens

sites, up to some $75 \mathrm{~m}$ in diameter (Fig. 22). The material culture remains from the Neolithic shell middens consist of chipped stone tools often obtained from Gadani dark red flint, among which are geometric microlithic inserts. They are represented by lunates and isosceles trapezes obtained from 


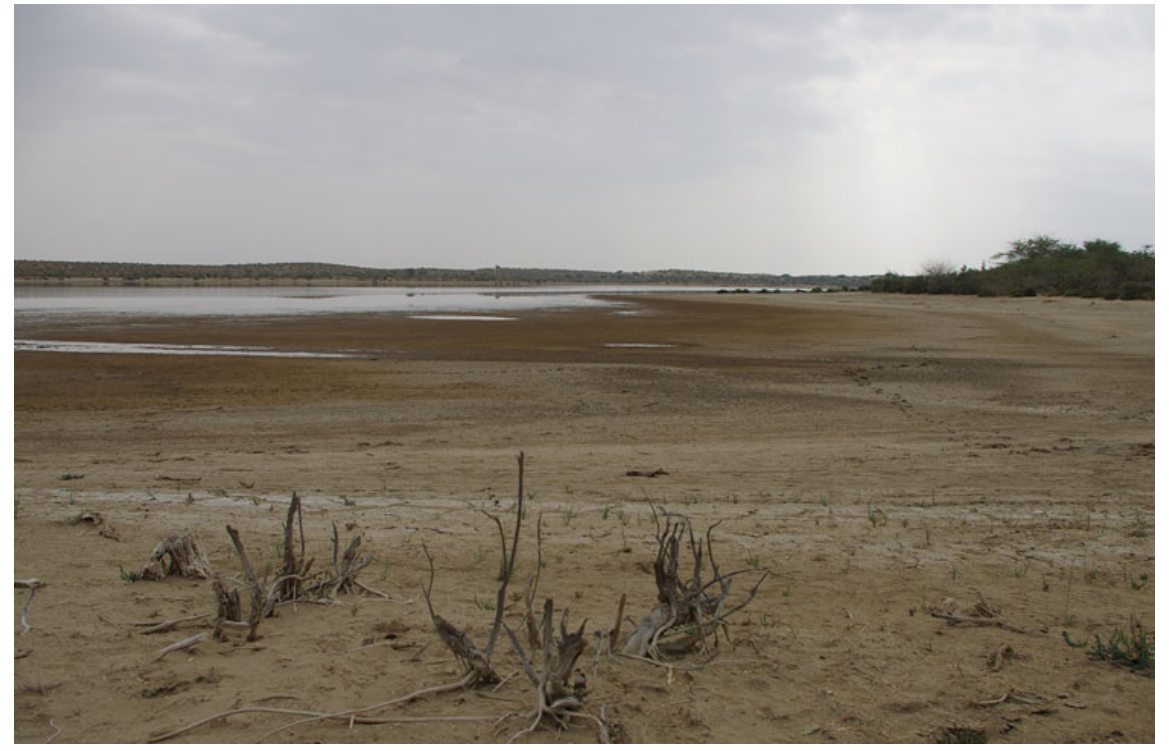

Fig. 18 Lake Siranda: part of the southeastern shore photographed in January 2013

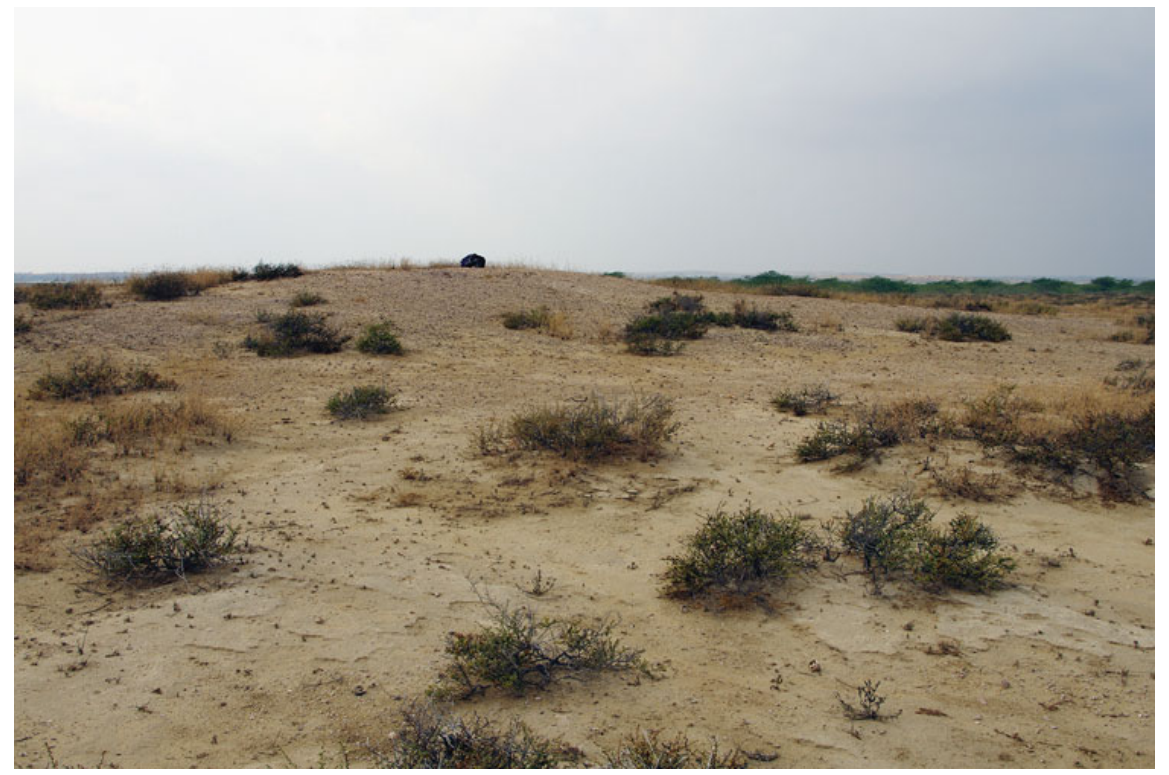

Fig. 19 Lake Siranda: the impressive shell mound 29

microbladelet blanks (Fig. 23). Coarse stone tools were also recovered, among which are lower querns and anvils (Fig. 24), as well as a few net weights. The results of the surveys carried out around the lake show that the depression was a shallow tidal lagoon surrounded by mangroves at least during the Neolithic and Chalcolithic periods. The basin emptied most probably around the end of the Bronze Age when the sea definitively reached the present-day level. At present some of the lake's surfaces are covered with millions of Melanoides tuberculata freshwater gastropods (Fig. 25) that might contribute to the interpretation of the events that took place after the retreat of the sea. The 


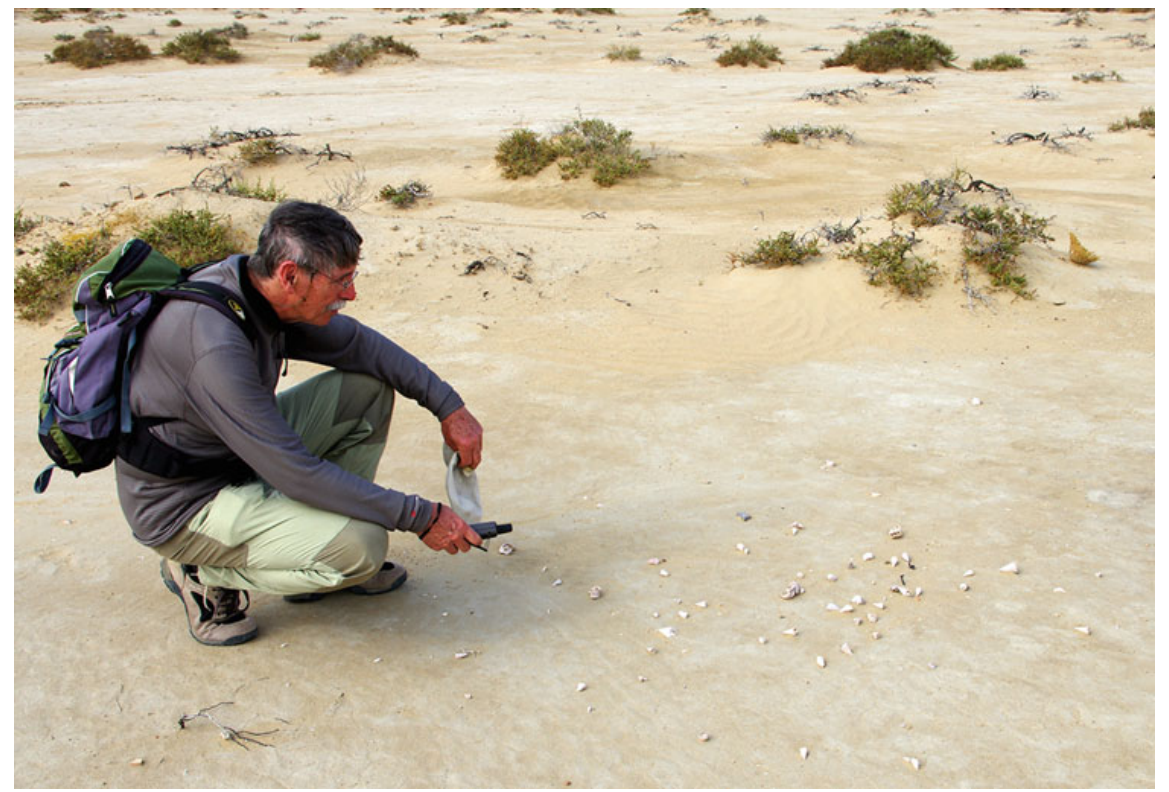

Fig. 20 Lake Siranda: shell scatter of site 30

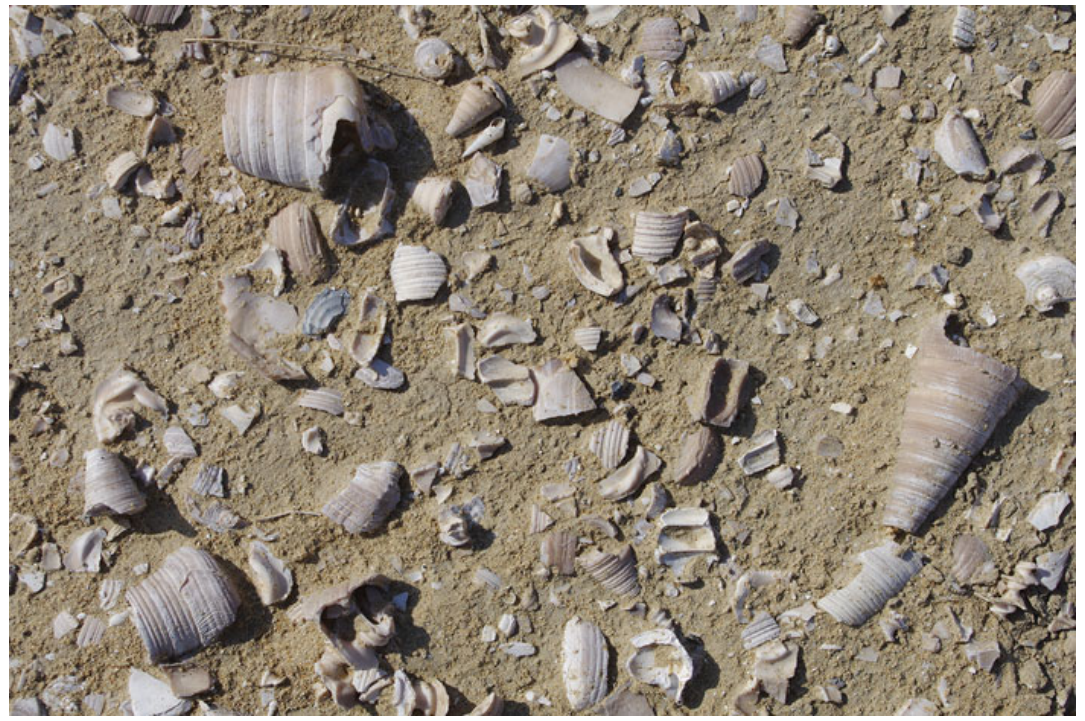

Fig. 21 Lake Siranda: shell midden 21 with Telescopium telescopium mangrove gastropods on its surface

AMS dating of a Melanoides sample retrieved in situ from a profile close to site 2 (Figs. 15, 26, and 27) yielded the result of $830 \pm 30$ uncal BP (GrA-57527), a date that marks some important event connected with the freshwater filling of the lake. 


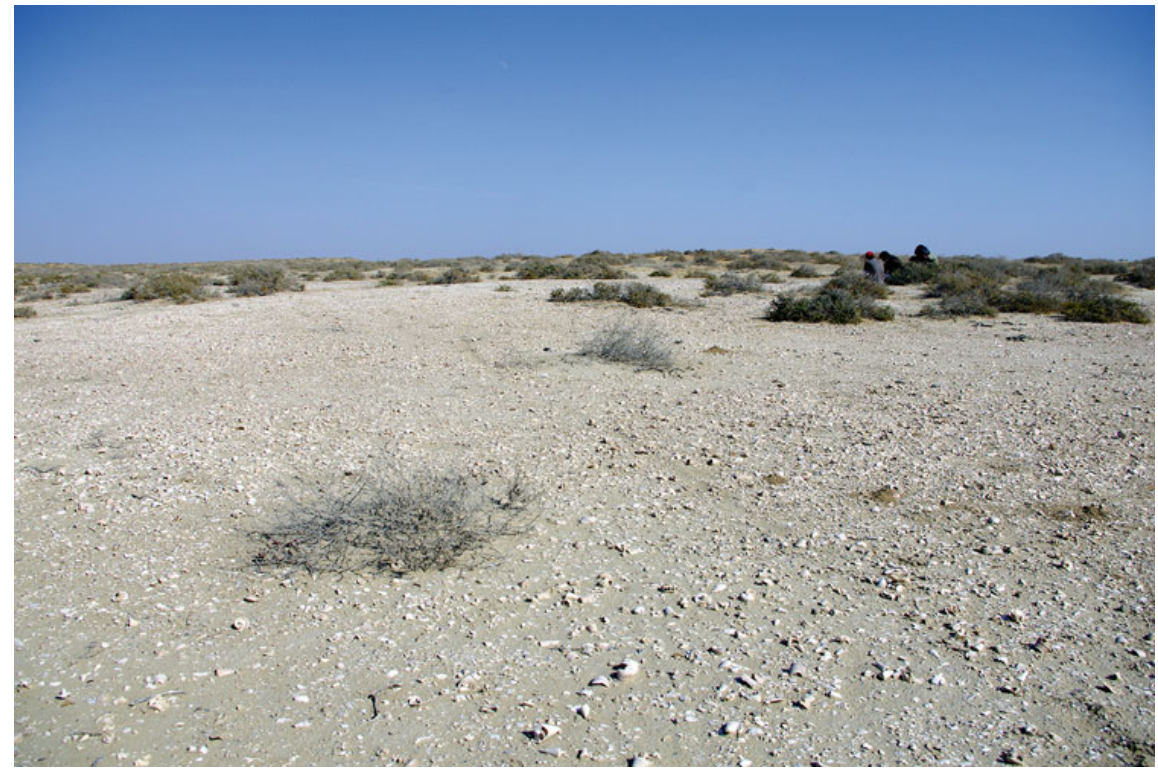

Fig. 22 Lake Siranda: surface of large shell midden 73

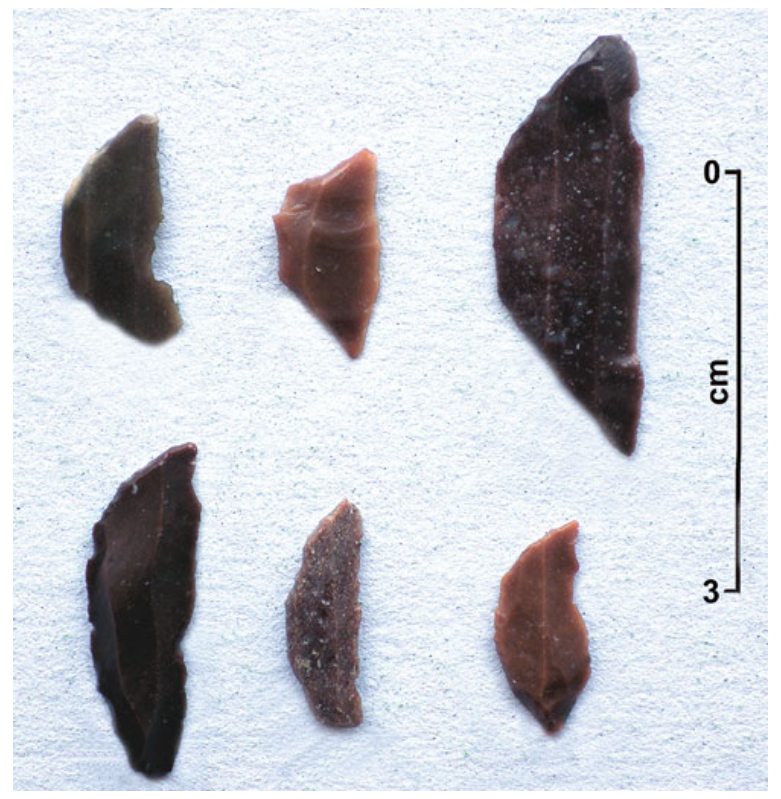

Fig. 23 Lake Siranda: geometric microlithic tools obtained from Gadani flint collected from the surface of shell midden 29. Top line, isosceles trapezes; bottom line, lunates

\section{Sonari}

Sonari is a very important Bronze Age village built on a terrace located at some $25-30 \mathrm{~m}$ of altitude west of the Hab River mouth (Fig. 28). The site was discovered by Professor A. R. Khan in the 1970s and never reported in any of his papers. The terrace was revisited in January 2001 (Biagi, 2004) and 


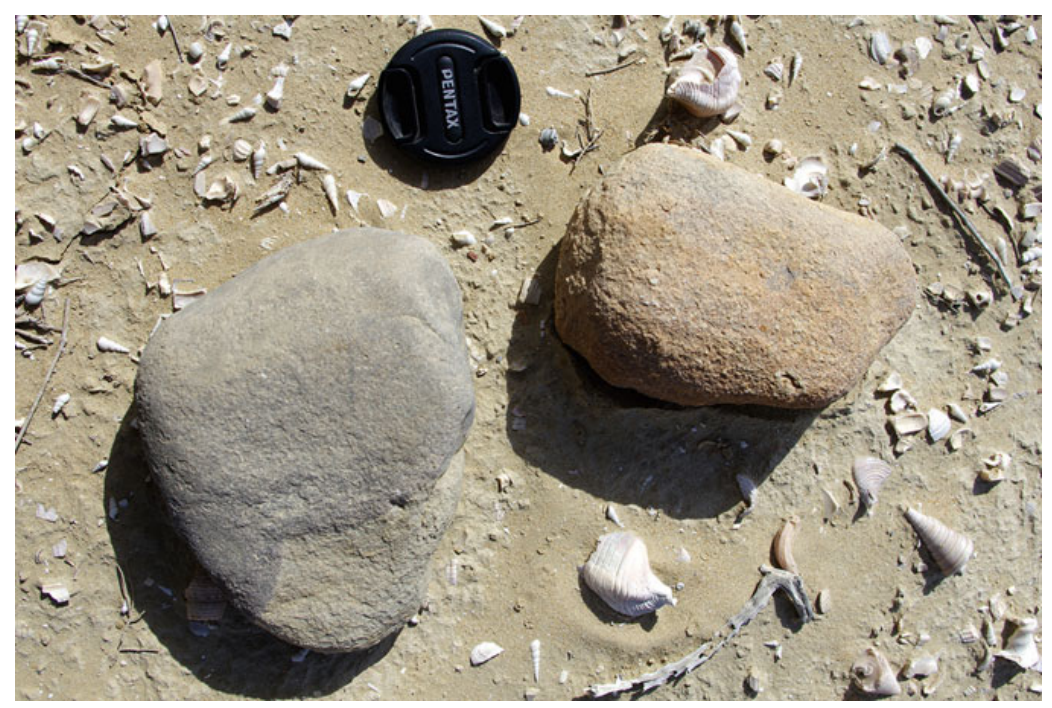

Fig. 24 Lake Siranda: coarse stone tools from the surface of shell midden 64

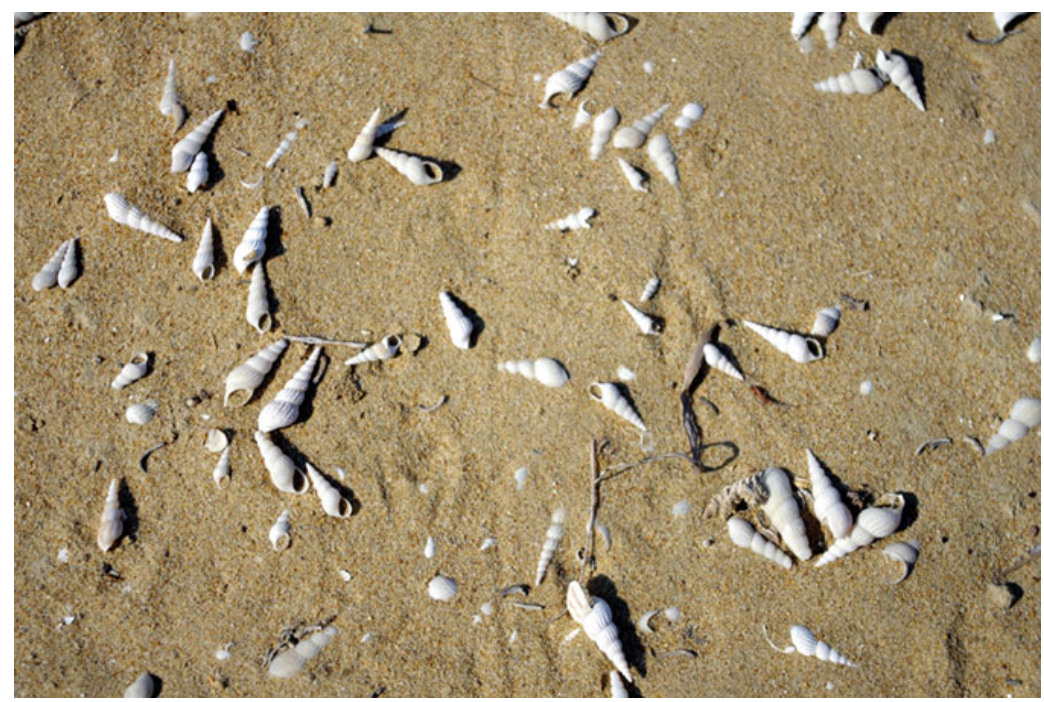

Fig. 25 Lake Siranda: surface of the basins rich in Melanoides tuberculata freshwater shells

systematically surveyed in August 2013. Apart from the above Bronze Age fishermen village that consists of rectangular stone structures, a few of which are covered with Meretrix marine bivalves (Fig. 29), traces of older shell middens have been recorded on the same terrace, at least one of which is to be attributed to the Neolithic because of the presence of characteristic lunate microliths. The Bronze Age village has been radiocarbon dated to dated to $4780 \pm 60$ uncal BP (GrA-59839) and $4850 \pm 60$ uncal BP (GrA-59837) from two specimens of Meretrix marine bivalves (Biagi \& Nisbet, 2014). From its surface come many net sinker (Fig. 30) ground stone tools, among which is a saddled lower quern, and a few potsherds. 


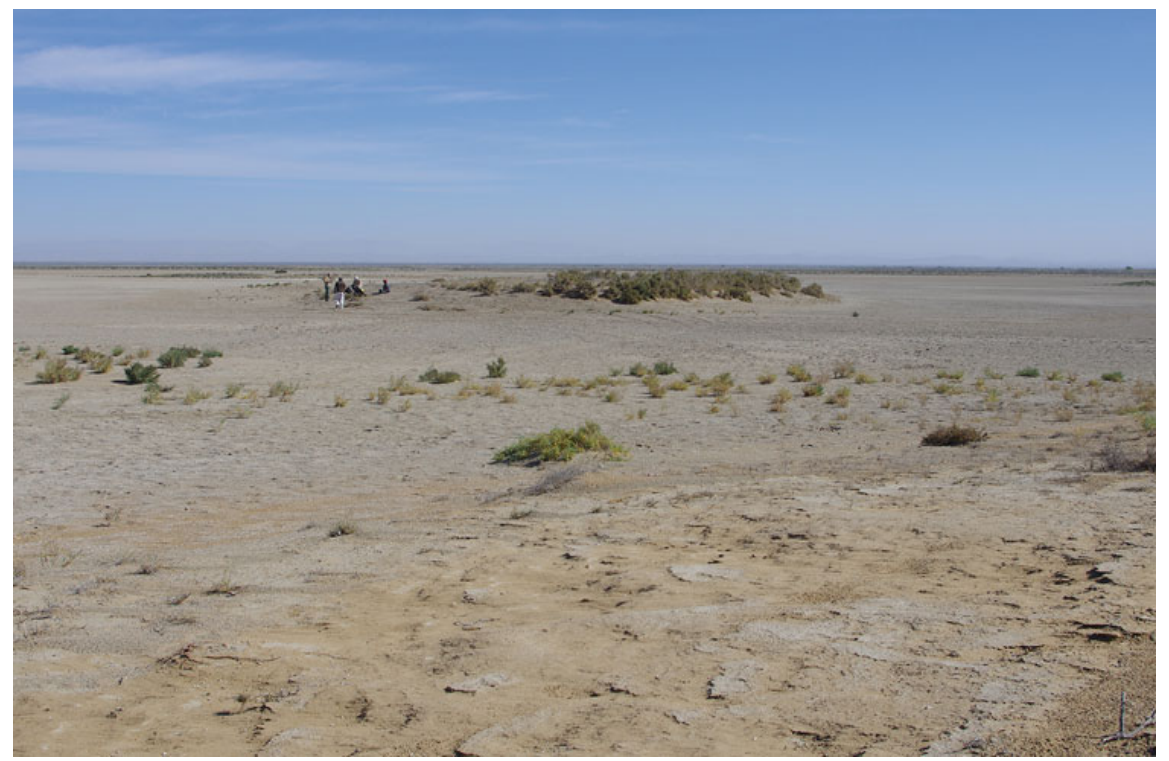

Fig. 26 Lake Siranda: the area of shell midden 2, where a profile containing Melanoides tuberculata freshwater shells was found in situ

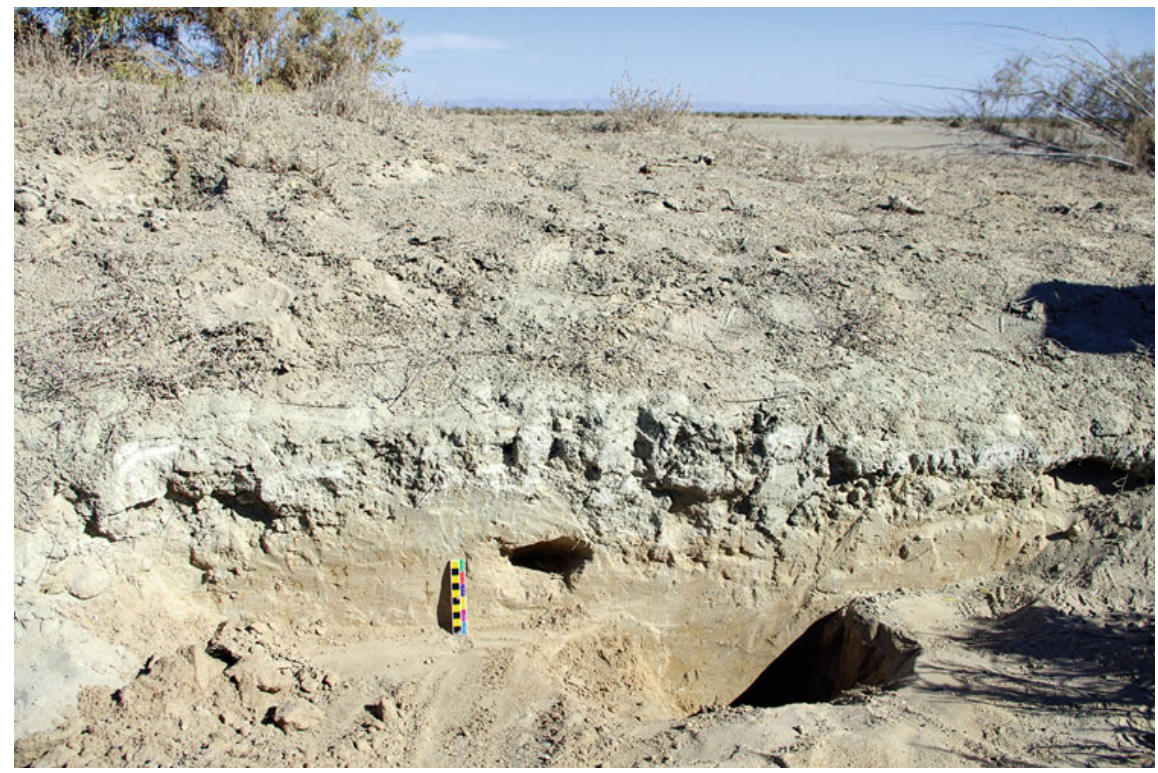

Fig. 27 Lake Siranda: profile close to shell midden 2, with location of the point from which a Melanoides tuberculata sample was taken for AMS dating 


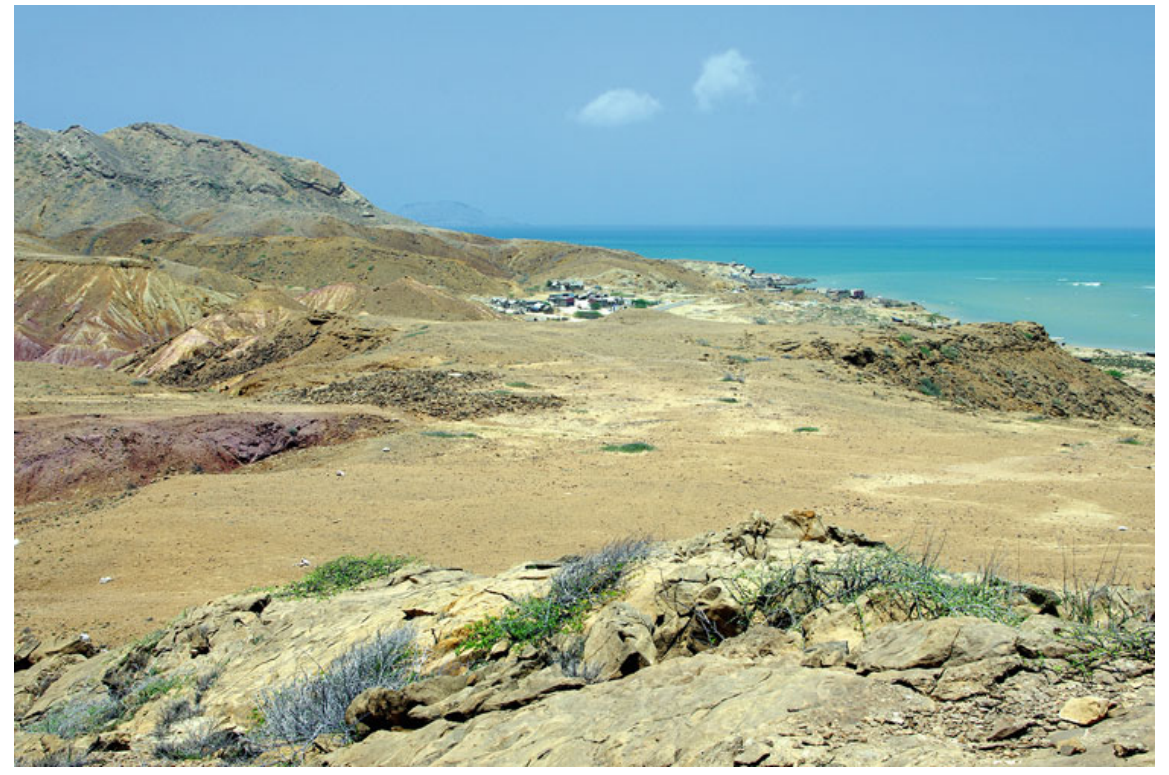

Fig. 28 Sonari: the terrace at the mouth of the Hab River where the Bronze Age site is located, in the center of the photograph

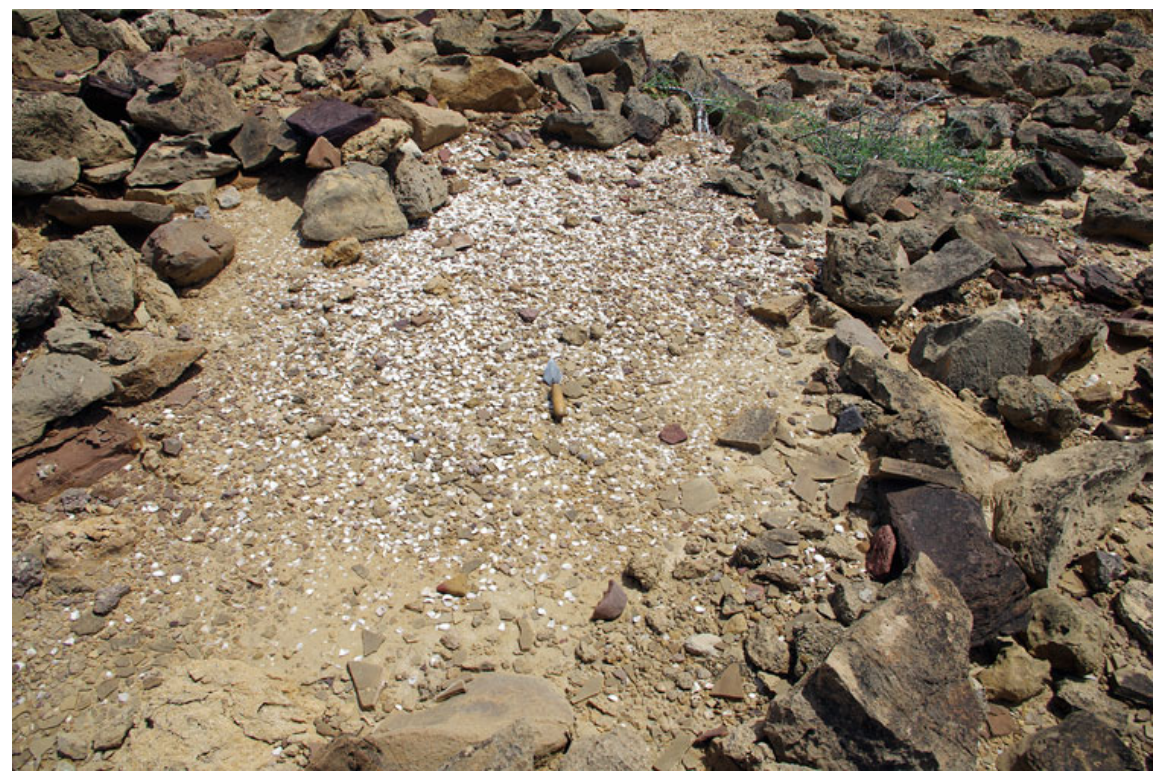

Fig. 29 Sonari: Bronze Age rectangular stone structure covered with Meretrix marine bivalves

\section{Considerations}

The data presented above show that the first Holocene peopling of Las Bela coast took place during the last centuries of the eighth millennium BP, when most of the shores of the Arabian Sea and the 


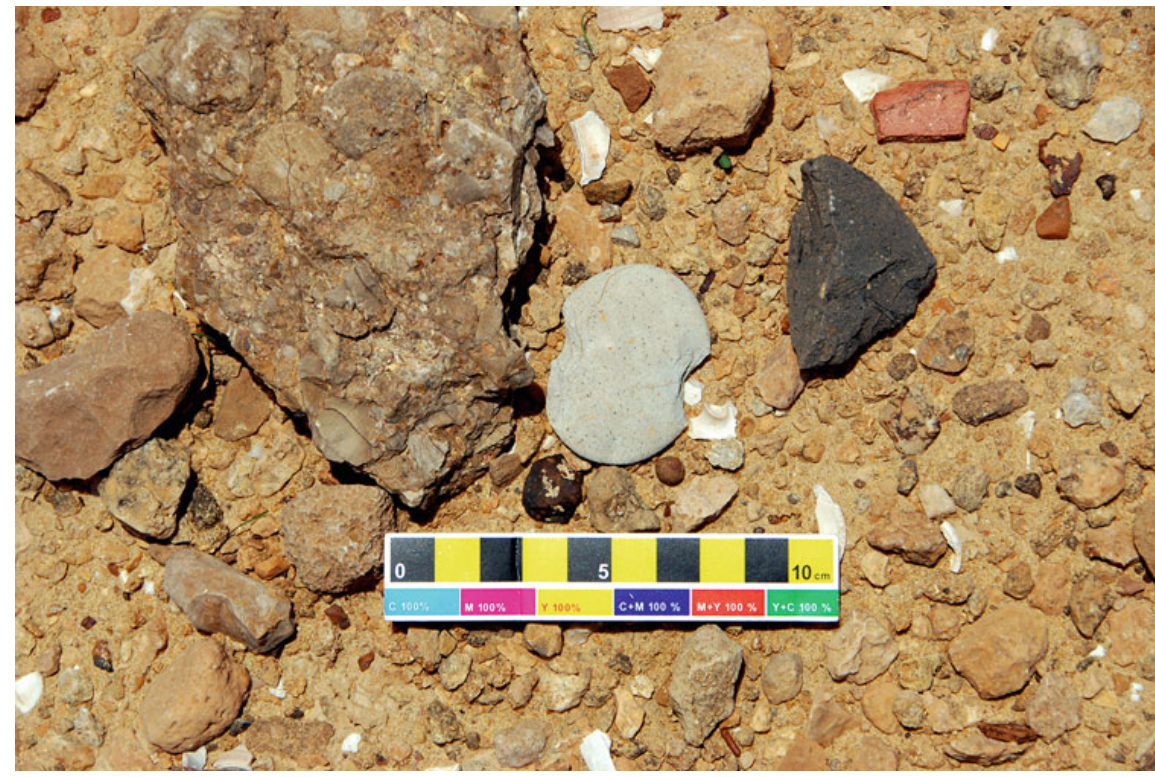

Fig. 30 Sonari: net sinker in situ on the surface of the Bronze Age village

Persian/Arabian Gulf started to be settled at least temporarily by fishers and shellfish gatherers who exploited the resources available from specialized mangrove environments (Biagi, 2008; Boivin \& Fuller, 2009). The discovery of shell middens around the shores of Lake Siranda is of major importance because it helps us define the geographic and environmental characteristics of some traits of the coastal landscape settled by the earliest Neolithic inhabitants of the northwestern corner of the Indian Ocean and compare it with the information available from other regions of the Arabian Sea, Oman, for example (Berger et al., 2013). In both countries the Neolithic coastal peopling seems to have followed the same trend, with fisher-gatherers exploiting well-developed mangrove environments along the shores of lagoons that started to dissect just after the retreat of the ocean waters that took place in the Bronze Age.

\section{Acknowledgment}

The author is very grateful to Dr. R. Nisbet and A. Girod, who took part in the Las Bela surveys, for providing Figures 11, 16 and 30 (R.N.) and for the identification of the marine shells (A.G.), and to Dr. T. Fantuzzi for the calibration of the radiocarbon dates.

\section{References}

Berger, J. F., Charpentier, V., Crassard, R., Martin, C., Davtian, G., \& López-Sáez, J. A. (2013). The dynamics of mangrove ecosystems, changes in sea level and strategies of Neolithic settlements along the coast of Oman (6000-3000 cal BC). Journal of Archaeological Science, 40, 3087-3104.

Biagi, P. (2003-2004). The Mesolithic Settlement of Sindh (Pakistan): A preliminary assessment. Praehistoria, 4-5, 195-220. 
Biagi, P. (2004). New radiocarbon dates for the prehistory of the Arabian Sea coasts of Lower Sindh and Las Bela in Balochistan. Rivista di Archeologia, 28, 5-16.

Biagi, P. (2008). The shell-middens of the Arabian Sea and the Gulf: Maritime connections in the seventh millennium BP? In A. R. Al-Ansary, K. I. Al-Muaikel, \& M. Alsharek (Eds.), The city in the Arab World in light of archaeological discoveries: Evolution and development (pp. 7-18). Riyadh: Abdul Rahman Al-Sudayri Foundation.

Biagi, P. (2011). Changing the prehistory of Sindh and Las Bela coast: twenty-five years of Italian contribution. World Archaeology, 43(4), 523-537.

Biagi, P. (2013). The shell middens of Las Bela coast and the Indus delta (Arabian Sea, Pakistan). Arabian Archaeology and Epigraphy, 24, 9-14.

Biagi, P., Fantuzzi, T., \& Franco, C. (2012). The shell middens of the Bay of Daun: Environmental changes and human impact along the coast of Las Bela (Balochistan, Pakistan) between the 8th and the 5th millennium BP. Eurasian Prehistory, 9(1-2), 29-49.

Biagi, P., Girod, A., Nisbet, R., \& Fantuzzi, T. (2013a). The middle holocene mangrove shellfish gatherers of Las Bela coast (Balochistan, Pakistan): New AMS dates from Lake Siranda shell middens. Antiquity Project Gallery, 87(337). http://Antiquity.ac.uk/projgall/biagi337

Biagi, P., Girod, A., \& Nisbet, R. (2013b). Prehistoric shell middens, seascapes and landscapes at Lake Siranda (Las Bela, Balochistan): Preliminary results of the 2011 survey. Journal of Asian Civilizations, 35(1), 1-25. Islamabad: Taxila Institute of Asian Civilizations.

Biagi, P., Nisbet, R., \& Girod, A. (2012-2013). The archaeological Sites of Gadani and Phuari Headlands (Las Bela, Balochistan, Pakistan). Journal of Indian Ocean Archaeology, 9, 75-86.

Biagi, P., \& Nisbet, R. (2014). Sonari: a Bronze Age fisher-gatherers settlement at the Hab River mouth (Sindh, Pakistan). Antiquity Project Gallery (in press).

Boivin, N., \& Fuller, D. (2009). Shell middens, ships and seeds: Exploring coastal subsistence, maritime trade and dispersal of domesticates in and around the Ancient Arabian Peninsula. Journal of World Prehistory, 22, 113-180.

De Cardi, B. (1983). Archaeological surveys in Baluchistan, 1948 and 1957 (Vol. 8). London: Institute of Archaeology Publication.

Khan, A. R. (1979). Ancient settlements in Karachi Region. In A. R. Khan (Ed.), Studies in geomorphology and prehistory of Sind (Grassroots, Special Issue 3.2, pp. 1-24). Jamshoro: University of Sind.

Khan, F. A. (1964). Las Bela and S.W. Expedition: 1959-60. Pakistan Archaeology, 1, 32-34.

Khan, R. A. (1973). Geological investigations of the area between Gadani and Cape Monze Pakistan. Government of Pakistan, Geological Survey of Pakistan. Information Release No. 66. Quetta: Director General, Geological Survey of Pakistan.

Kristiansen, K. (2002). The Birth of Ecological Archaeology in Denmark: history and research environments 1850-2000. In A. Fischer \& K. Kristiansen (Eds.), The Neolithisation of Denmark 150 years of debate (pp. 11-31). Sheffield: J. R. Collins Publications.

McCrindle, J. W. (1973). The commerce and navigation of the erythrcean sea: Being a translation of the periplus maris erythrcei by an anonymous writer and partly from Arrian's account of the Voyage of Nearchus. Amsterdam: Pjhilo Press (1st reprint).

Minchin, C. F. (1907). Las Bela. Text and appendices. Karachi: Indus Publications.

Naseem, S., Sheikh, S. A., \& Qadeeruddin, M. (1996-1997). Geochemistry and Tectonic Setting of Gadani-Phuari Segment of Las Bela Ophiolites, Balochistan, Pakistan. Journal of King Abdulaziz University. Earth Sciences 9, 127-144.

Raikes, R. L. (1967-1968). Archaeological explorations in southern Jhalawan, and Las Bela (Pakistan). Origini 2, 103-171. 
Sarwar, G. (1992). Tectonic setting of the Bela Ophiolites, Southern Pakistan. Tectonophysics, 207, 359-381.

Snead, R. E. (1966). Physical Geography Reconnaissance: Las Bela Coastal Plain, West Pakistan (Louisiana State University Studies Coastal Studies Series 13, pp. 1-117). Baton Rouge: Louisiana State University Press.

Snead, R. E. (1969). Physical Geography Reconnaissance: West Pakistan Coastal Zone (University of New Mexico Publications in Geography 1). Albuquerque: University of New Mexico Department of Geography.

Snead, R. E., \& Frishman, S. A. (1968). Origin of sands on the east side of Las Bela Valley, West Pakistan. Geological Society of America Bulletin, 79, 1671-1676.

Stein, A. (1943). On Alexander's Route into Gedrosia: An Archaeological Tour in Las Bela. The Geographical Journal, 102(5-6), 193-227. 